\title{
CEGAH PENYAKIT TUBERKULOSIS DI PUSKESMAS HARAPAN RAYA KOTA PEKANBARU
}

\author{
Yuyun Priwahyuni' ${ }^{1)}$, Christine Vita Gloria ${ }^{2)}$, Agus Alamsyah ${ }^{3)}$, Ikhtiyaruddin ${ }^{4)}$, \\ Fathur Rahman ${ }^{5}$, Afernia Chindyta ${ }^{6}$ \\ 1,2,3,4,5,6) Prodi Kesehatan Masyarakat, STIKes Hang Tuah Pekanbaru \\ Email: yuyun.priwahyuni@gmail.com
}

\begin{abstract}
ABSTRAK
Tuberkulosis (TB) adalah penyakit infeksi yang disebabkan oleh Mycobacterium tuberculosis. Hingga saat ini, tuberkulosis masih menjadi penyakit infeksi menular yang paling berbahaya di dunia. Selama ini penyakit infeksi seperti TB diatasi dengan penggunaan antibiotik. Rifampisin (RIF), Isoniazid (INH), etambutol (EMB), streptomisin dan pirazinamid (PZA) telah dimanfaatkan selama bertahuntahun sebagai anti-TB. Namun, banyak penderita telah menunjukkan resistensi terhadap obat lini pertama ini. Sejak tahun 1980-an, kasus tuberkulosis di seluruh dunia mengalami peningkatan karena kemunculan MDR-TB (Multi Drug Resisten Tuberculosis). Bakteri penyebab MDR-TB adalah strain M. tuberculosis yang resisten terhadap obat anti-TB first-line seperti isoniazid dan rifampisin. Kepada pihak terkait seperti DinKes, puskesmas, dapat mengagendakan kegiatan ini secara rutin, pihak Puskesmas Harapan Raya Pekanbaru agar dapat memanfaatkan dan melakukan edukasi kepada pasien yang hadir di Puskesmas Harapan Raya Pekanbaru
\end{abstract}

Kata Kunci : Tuberkulosis, Resistensi

\section{ABSTRACT}

Tuberculosis (TB) is an infectious disease caused by Mycobacterium tuberculosis. Until now, tuberculosis is still the most dangerous infectious disease in the world. During this time, infectious diseases such as TB are treated with antibiotics. Rifampicin (RIF), Isoniazid (INH), ethambutol (EMB), streptomycin and pyrazinamide (PZA) have been used for many years as anti-TB. However, many sufferers have shown resistance to this first-line drug. Since the 1980s, tuberculosis TB worldwide has increased due to the emergence of MDR-TB (Multi Drug Resistant Tuberculosis). The bacteria that cause MDR-TB are M. tuberculosis strains that are resistant to first-line anti-TB drugs such as isoniazid and rifampicin. Related parties such as DinKes, Puskesmas, can schedule this activity, Puskesmas Harapan Raya Pekanbaru can utilize and educate patients who are present at Harapan Raya Puskesmas Pekanbaru

Keywords: Tuberculosis, Resistance 


\section{PENDAHULUAN}

Tuberkulosis (TB) adalah penyakit infeksi yang disebabkan oleh Mycobacterium tuberculosis. Hingga saat ini, tuberkulosis masih menjadi penyakit infeksi menular yang paling berbahaya di dunia. World Health Organization (WHO) melaporkan bahwa sebanyak 1,5 juta orang meninggal karena TB (1.1 juta HIV negatif dan 0.4 juta HIV positif) dengan rincian 89.000 laki-laki, 480.000 wanita dan 140.000 anak-anak. Pada tahun 2014, kasus TB diperkirakan terjadi pada 9,6 juta orang dan $12 \%$ diantaranya adalah HIV-positif (WHO, 2015).

Berdasarkan Global Tuberculosis Report 2015 yang dirilis oleh WHO, sebanyak 58\% kasus TB baru terjadi di Asia Tenggara dan wilayah Western Pacific pada tahun 2014. India, Indonesia dan Tiongkok menjadi negara dengan jumlah kasus TB terbanyak di dunia, masing-masing $23 \%, 10 \%$ dan $10 \%$ dari total kejadian di seluruh dunia. Indonesia menempati peringkat kedua bersama Tiongkok. Satu juta kasus baru pertahun diperkirakan terjadi di Indonesia (WHO, 2015).

Selama ini penyakit infeksi seperti TB diatasi dengan penggunaan antibiotik. Rifampisin (RIF), Isoniazid (INH), etambutol (EMB), streptomisin dan pirazinamid (PZA) telah dimanfaatkan selama bertahuntahun sebagai anti-TB. Namun, banyak penderita telah menunjukkan resistensi terhadap obat lini pertama ini. Sejak tahun 1980an, kasus tuberkulosis di seluruh dunia mengalami peningkatan karena kemunculan MDR-TB (Multi Drug Resisten Tuberculosis) (Chan dkk, 2002).

Menurut data yang diperoleh dari Puskesmas Harapan Raya Kota Pekanbaru, terhitung Januari hingga akhir Februari 2019 terdapat sebanyak 195 warga terkena penyakit tuberculosis dan merupakan penyakit dengan jumlah penderita terbanyak. Penyebab tingginya kasus ini yaitu kuman dan bakteri yang menyebar di udara dan terhirup oleh penderita tanpa sepengetahuan mereka.

\section{TINJAUAN PUSTAKA}

Bakteri penyebab MDR-TB adalah strain $M$. tuberculosis yang resisten terhadap obat anti-TB first-line seperti isoniazid dan rifampisin. MDR-TB mendorong penggunaan obat lini kedua yang lebih toksik seperti etionamid, sikloserin, kanamisin dan kapreomisin (Tripathi dkk., 2005). Namun extensively drug-resisten tuberculosis (XDR-TB) menyebabkan bakteri TB resisten terhadap obat lini kedua (WHO, 2010).

Organisasi Kesehatan Dunia memperkirakan 9 juta kasus tuberkulosis baru terjadi secara global pada tahun 2013 dan sebanyak 480.000 kasus diantaranya adalah multi drug-resistant TB (MDR-TB). Hanya seperempat dari jumlah kasus MDR tersebut (kurang lebih 123.000) terdeteksi dan dilaporkan. Sementara itu, XDR-TB dilaporkan terjadi di 105 negara pada tahun 2015. Sekitar 9,7\% pasien dengan MDRTB diperkirakan memiliki XDR-TB (WHO, 2015).

Sebagian besar obat TB yang digunakan saat ini dikembangkan lebih dari 40 tahun lalu. Kemunculan kasus resistensi terhadap obat lini pertama dan kedua serta kerumitan dan lamanya waktu terapi TB saat ini mendorong upaya pencarian dan penemuan obat anti-tuberkulosis baru. Perpendekkan dan penyederhanaan durasi terapi, efektifitas terhadap MDR dan XDR-TB dan kompatibilitas pemberian bersama antiretroviral adalah regimen pengobatan baru yang saat ini diperlukan oleh dunia. Beberapa dekade ini, muncul senyawa-senyawa baru yang saat ini sedang dalam tahap percobaan preklinis maupun klinis. Senyawa-senyawa tersebut memiliki aktivitas potensial untuk melawan 
strain M. tuberculosis sensitif dan resisten. Hal ini dapat menjadi harapan bagi kemajuan terapi TB di masa depan (Villemagne dkk., 2012).

\section{METODE PELAKSANAAN}

Bentuk kegiatan pemberdayaan yang dilaksanakan adalah mengenai tuberkulosis dan pendidikan kesehatan berupa ceramah. Kegiatan mengenai tuberkulosis dan pendidikan kesehatan berupa ceramah dilakukan oleh para pengabdi dan dibantu oleh para mahasiswa STIKes Hang Tuah Pekanbaru peminatan Promosi Kesehatan dan Ilmu Perilaku. Sebelum para peserta yakni pasien yang datang berobat diberikan, para pasien diberikan pertanyaan terlebih dahulu untuk mengetahui pengetahuan pasien terkait tuberkulosis.

\section{HASIL DAN PEMBAHASAN}

Kegiatan Pemberdayaan Masyarakat Mengenai Tuberkulosis, Kegiatan diikuti oleh para pasien yang berjumlah 50 orang, kegiatan dilaksanakan pada hari Rabu, 18 Desember 2019 yang dimulai pukul 07.30 WIB sampai dengan selesai. Pengabdi berkoordinasi dengan pihak puskesmas untuk menyediakan tempat kegiatan dan juga layar proyektor.

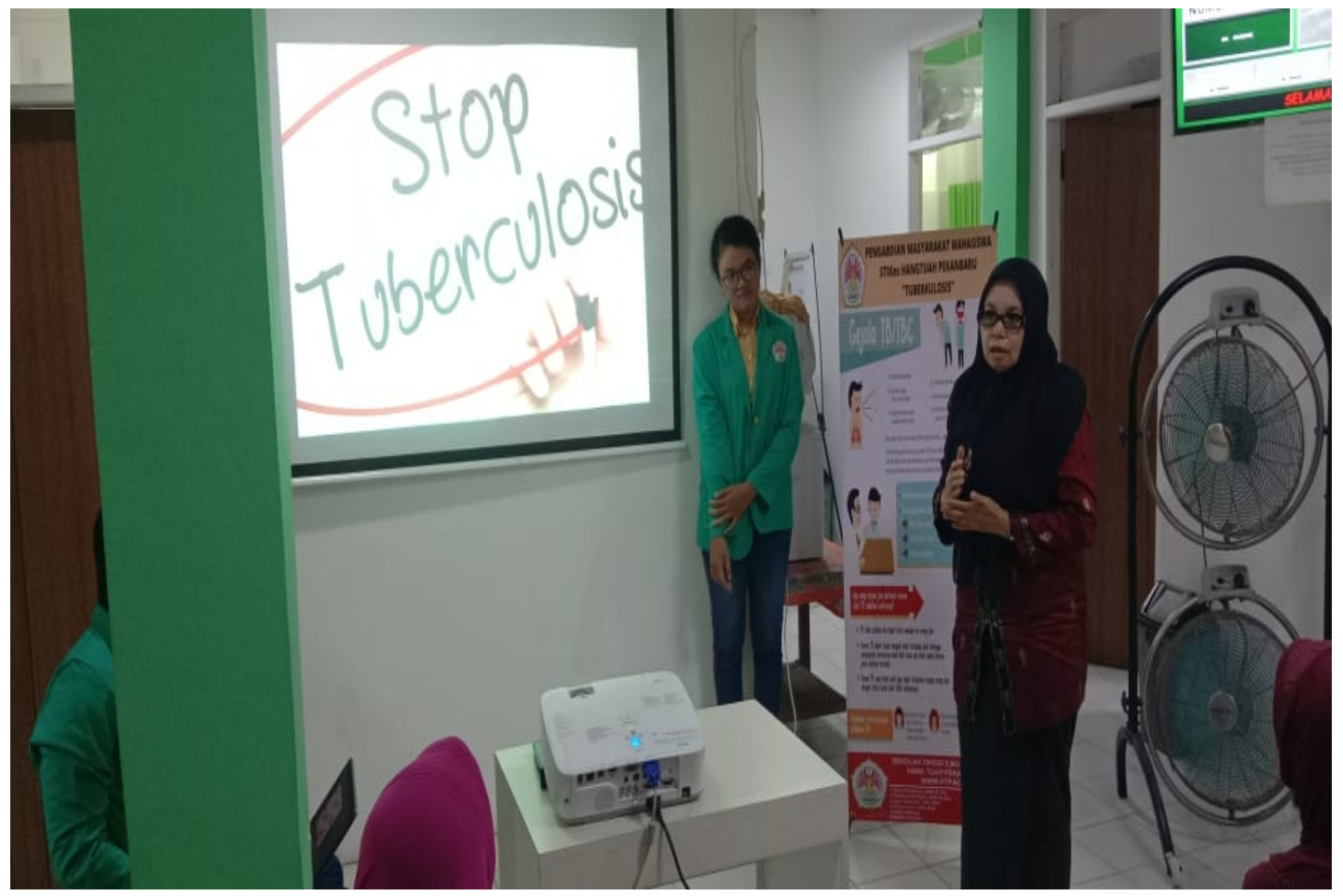

Gambar 1. Kegiatan Pemberian Materi 


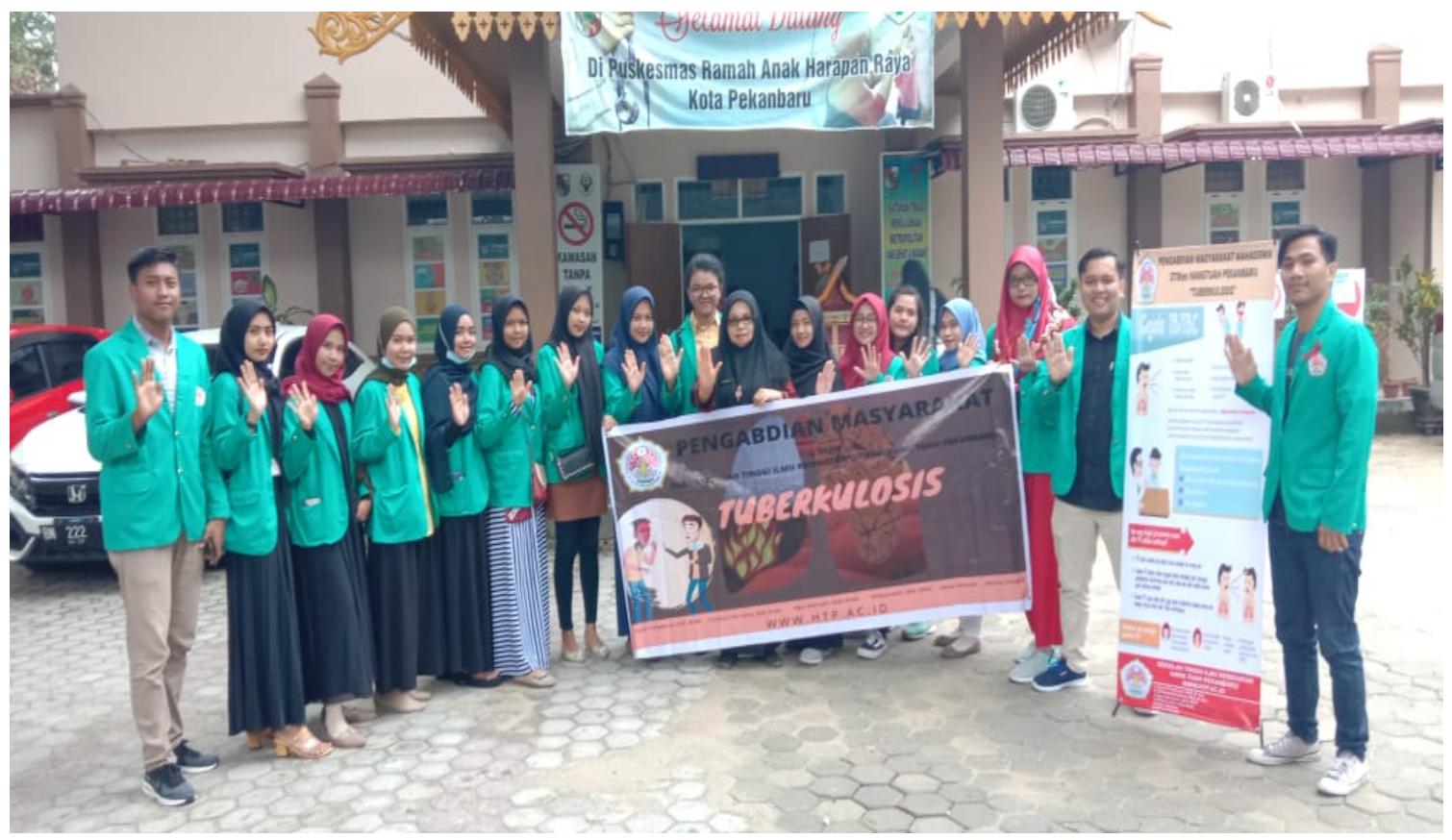

Gambar 2. Tim Pengabdi

Dari hasil tersebut dapat terlihat bahwa dari 20 pasien yang mengikuti kegiatan tersebut, hanya $45 \%$ pasien yang mengetahui apa itu tuberkulosis. Setelah para pengabdi menyampaikan materi, para pasien diberikan pertanyaan kembali mengenai tuberkulosis. Hasil yang didapat bahwa dari 20 pasien yang mengikuti kegiatan tersebut $80 \%$ pasien mengetahui apa itu tuberkulosis berupa berbagai gejala yang terjadi. Kegiatan pengabdian mengenai tuberkulosis dan pendidikan kesehatan berupa ceramah sangat efektif dilaksanakan pada pasien puskesmas harapan raya kota pekanbaru.

Melaksanakan Pemberdayaan Masyarakat mengenai tuberkulosis yang dilaksanakan di Puskesmas harapan raya kota pekanbaru merupakan salah satu bentuk meningkatkan pengetahuan pasien agar lebih mengetahui lagi mengenai penyakit tuberkulosis yang tentunya masih banyak masyarakat yang kurang tau akan penyakit tersebut.

Diagnosis TB paru ditegakkan melalui pemeriksaan gejala klinis, mikrobiologi, radiologi, dan patologi klinik. Gejala klinik TB dapat dibagi menjadi 2 golongan, yaitu gejala respiratorik (atau gejala organ yang terlibat) dan gejala sistemik. Gejala respiratorik meliputi batuk lebih dari 3 minggu, batuk disertai darah, sesak napas, dan nyeri dada. Semua gejala ini sangat bervariasi, dimulai tidak ada gejala sampai gejala cukup berat tergantung luasnya perlukaan pada paru. Gejala tuberkulosis ekstra paru tergantung dari organ yang terlibat, misalnya pada limfadenitis tuberkulosa akan terjadi pembesaran yang lambat dan tidak nyeri dari kelenjar getah bening, pada meningitis tuberkulosa akan terlihat gejala meningitis, sementara pada pleuritis tuberkulosa terdapat gejala sesak napas \& kadang nyeri dada pada sisi yang rongga pleuranya terdapat cairan. Gejala sistemik meliputi demam dari rendah sampai tinggi, dan disertai dengan gejala sistemik yang lain seperti malaise, anoreksia, keringat malam, dan berat badan menurun yang merupakan ciri khas TB selain batuk berkepanjangan (Departemen Kesehatan Republik Indonesia, 2005). 
Pemeriksaan Fisik, pada tuberkulosis paru, kelainan yang didapat tergantung luas kelainan struktur paru. Apabila dilakukan pemeriksaan pada awal perkembangan penyakit biasanya sulit atau tidak ditemukan kelainan.. Kelainan paru pada umumnya terletak di daerah lobus superior terutama daerah apex dan segmen posterior, serta daerah apex lobus inferior. Pada pemeriksaan fisik dapat ditemukan kelainan dengan mendengarkan suara nafas dengan menggunakan stetoskop, ditemukan antara lain suara napas bronkial, amforik, suara napas melemah, ronki basah, dan pada tanda lain adalah penarikan paru, diafragma \& mediastinum (Perhimpunan Dokter Paru Indonesia, 2006). Pemeriksaan Bakteriologik, pemeriksaan dahak berfungsi untuk menegakkan diagnosis, menilai keberhasilan pengobatan dan menentukan potensi penularan. Pemeriksaan dahak untuk penegakan diagnosis dilakukan dengan mengumpulkan 3 spesimen dahak yang dikumpulkan dalam dua hari kunjungan yang berurutan sewaktu-pagi-sewaktu (SPS) (Kementrian Kesehatan RI, 2012). Laboratorium Mikroskopis merupakan penunjang utama untuk tata laksana pasien Tuberkulosis. Ketersediaan perangkat laboratorium mikroskopis tidak dapat dipisahkan dalam memberikan pelayanan tata laksana pasien TB selain obat anti tuberkulosis (OAT).

Faktor-faktor yang mempengaruhi pemeriksaan dahak mikroskopis TB adalah faktor di dalam laboratorium (pembuatan sediaan, pembacaan sediaan, pencatatan dan pelaporan) dan faktor di luar laboratorium (pasien, petugas kesehatan, pengambilan sampel, pengadaan logistik, pengelola program). Pemeriksaan Radiologik, pemeriksaan standar adalah foto toraks PA. Pemeriksaan lain atas indikasi ialah foto lateral, top lordotik, oblik, CTScan. Pada kasus dimana pada pemeriksaan sputum SPS positif, foto toraks tidak diperlukan lagi. Pada beberapa kasus dengan hapusan positif perlu dilakukan foto toraks bila ; Curiga adanya komplikasi (misal: efusi pleura, pneumotoraks), Hemoptisis berulang atau berat, Didapatkan hanya 1 spesimen BTA +.

Penyuluhan berasal dari kata suluh yang berarti pemberi terang ditengah kegelapan. Metode ceramah bertujuan untuk memberikan nasehat dan petunjuk-petunjuk kepada peserta penyuluhan. Tanya jawab antara petugas kesehatan dengan audience untuk menggali informasi mengenai ia tidak tau atau belum menerima perubahan, ia tertarik atau belum menerima perubahan untuk mempengaruhi apakah perilaku sudah atau yang akan mempunyai dasar pengertian dan kesadaran yang kuat.

\section{KESIMPULAN}

Kesimpulan dari kegiatan pengabdian masyarakat tentang cegah penyakit tuberkulosis adalah sebagai berikut :

1. Masyarakat mendapatkan pengetahuan baru tentang bagaimana mencegah penularan penyakit TB dan faktor resiko terserang penyakit TB dengan diadakannya kegiatan tersebut.

2. Masyarakat mengetahui apa saja gejala terkena penyakit TB.

3. Tersedia media promosi kesehatan berupa spanduk dan banner.

Ucapan terimakasih kami sampaikan kepada Pusat Penelitian dan Pengabdian Masyarakat STIKes Hang Tuah Pekanbaru sebagai pemberi dana dalam kegiatan pengabdian masyarakat yang telah dilaksanakan pada bulan Desember 2019. Serta ucapan terimakasih kepada Puskesmas Harapan Raya Kota Pekanbaru yang telah memberikan kesempatan dalam pelaksanaan pengabdian masyarakat. 


\section{DAFTAR PUSTAKA}

[1]. Department of Gender and Women's Health of WHO. Gender and Tuberculosis. Geneva: Department of Gender and Women's Health of WHO. 2002.

[2]. Hiswani. Tuberkulosis Merupakan Penyakit Infeksi yang Masih Menjadi Masalah Kesehatan Masyarakat. Fakultas Kesehatan Masyarakat Sumatera Utara. 2004.

[3]. Ndungu, PW. Risk Factor in the Transmission of Tuberculosis in Naairobi: A Descriptive Epidemiological study. Kenya. Scientific Research: Advances in Microbiology. 3;160-165. 2013.

[4]. Notoatmodjo, Soekijo. Promosi Kesehatan Teori dan Aplikasinya. Jakarta: Rineka Cipta. 2005.

[5]. World Health Organization (WHO). Global Tuberculosis Report 2015. Switzerland. 2015. 